\title{
Improved clinical tolerance to chronic lactose ingestion in subjects with lactose intolerance: a placebo effect?
}

\author{
F Briet, P Pochart, P Marteau, B Flourie, E Arrigoni, J C Rambaud
}

\begin{abstract}
Background-Uncontrolled studies of lactose intolerant subjects have shown that symptom severity decreases after chronic lactose consumption. Adaptation of the colonic flora might explain this improvement.

Aims-To compare the effects of regular administration of either lactose or sucrose on clinical tolerance and bacterial adaptation to lactose.

Methods-Forty six lactose intolerant subjects underwent two 50 g lactose challenges on days 1 and 15 . Between these days they were given $34 \mathrm{~g}$ of lactose or sucrose per day, in a double blind protocol. Stool samples were obtained on days 0 and 14 , to measure faecal $\beta$-galactosidase and pH. Symptoms, breath $\mathrm{H}_{2}$ excretion, faecal weight and electrolytes, and orofaecal transit time were assessed.

Results-Except for faecal weight, symptoms were significantly milder during the second challenge in both groups, and covariance analysis showed no statistical difference between them. In the lactose group, but not in the sucrose group, faecal $\beta$-galactosidase activity increased, $\mathrm{pH}$ dropped, and breath $\mathrm{H}_{2}$ excretion decreased.

Conclusion-Bacterial adaptation occurred when lactose intolerant subjects ingested lactose for 13 days, and all symptoms except diarrhoea regressed. Clinical improvement was also observed in the control group which displayed no signs of metabolic adaptation. This suggests that improved clinical tolerance may be just a placebo effect.

(Gut 1997; 41: 632-635)
\end{abstract}

Keywords: lactose; lactose intolerance; colonic adaptation; lactase deficiency

More than $70 \%$ of adults throughout the world experience lactose maldigestion due to a genetically programmed loss of intestinal lactase activity. ${ }^{1}$ As a result, some of them suffer from abdominal complaints, including diarrhoea, when ingesting lactose, a condition known as lactose intolerance. ${ }^{1}$ Several reports which especially concern school milk feeding programmes in developing countries have suggested that in lactose maldigestion, chronic milk consumption increases the amount of lactose that can be tolerated without symptoms, and thus improves milk acceptance. ${ }^{2}{ }^{3}$ It has been postulated that such clinical tolerance might be due to the metabolic adaptation of the colonic microflora to the chronic arrival of lactose. Both improved tolerance and bacterial metabolic adaptation were indeed induced by chronic ingestion of lactulose, an indigestible disaccharide closely related to lactose. ${ }^{4}$ However, the possibility that some lactose intolerance symptoms might be due to underlying irritable bowel syndrome-in which the placebo effect is high - has also been proposed, ${ }^{67}$ and the lack of appropriate blinded trials was recently emphasised. ${ }^{7}$

This double blind controlled study aimed to compare the effects of prolonged administration of either lactose or sucrose on lactose intolerance symptoms and bacterial colonic metabolism in lactose intolerant subjects. We observed that metabolic adaptation of the flora, and a decrease in symptoms occurred in the group given lactose, and that a similar reduction in symptoms, but not bacterial adaptation, occurred in the sucrose group, thus showing that the clinical improvement does not result from the metabolic adaptation, but rather from acclimatisation to the test - that is, a placebo effect.

\section{Methods}

SUBJECTS

Forty six healthy volunteers with lactose malabsorption and lactose induced diarrhoea were studied. There were 21 males and 25 females, all of Asian origin, whose mean (SEM) age was 33 (7) years (range 20-47 years). None had experienced gastrointestinal disturbances, or been given antibiotics, laxatives, or enemas during the month preceding the study. Subjects were selected for participation on the basis of a rise in their breath hydrogen $\left(\mathrm{H}_{2}\right)$ concentration to over 20 parts per million associated with one liquid stool or three bowel movements within six hours of ingesting $50 \mathrm{~g}$ lactose in $250 \mathrm{ml}$ water. All subjects avoided milk in their usual diet. The study was approved by the Ethics Committee of the Lariboisière, Saint-Louis, Saint-Lazare hospitals, and all investigations were undertaken after informed consent had been given by the subjects.

\section{EXPERIMENTAL DESIGN}

The subjects remained on their accustomed diet and were studied during two lactose challenges on days 1 and 15, separated by a 13 day 
TABLE 1 Clinical tolerance, faecal characteristics and breath $\mathrm{H}_{2}$ excretion in lactose intolerant subjects during a $50 \mathrm{~g}$ lactose challenge before (day 1 ) and after (day 15) prolonged consumption of lactose $(n=24)$ or sucrose $(n=22)$

\begin{tabular}{|c|c|c|c|c|c|c|}
\hline & \multicolumn{2}{|l|}{ Day 1} & \multicolumn{2}{|l|}{ Day 2} & \multirow{2}{*}{$\begin{array}{l}\text { Difference in adjusted } \\
\text { means lactose-sucrose } \\
(95 \% \text { CI })\end{array}$} & \multirow{2}{*}{$\begin{array}{l}p \text { Value } \\
(\text { ANCOVA })\end{array}$} \\
\hline & Lactose group & Sucrose & Lactose group & Sucrose group & & \\
\hline Clinical score $(0-144)$ & $42.1(19.9)$ & $42.0(15.2)$ & $20.2(13.9) \ddagger$ & $24.2(12.8) \ddagger$ & $-4.0 \quad(-11.7$ to 3.7$)$ & NS \\
\hline Number of stools & $3.7(1.5)$ & $4.2(2.7)$ & $2.0 \quad(1.2) \ddagger$ & $2.4(1.8)+$ & $-0.3(-1.2$ to 0.6$)$ & NS \\
\hline Faecal weight $(\mathrm{g} / 24 \mathrm{~h})$ & 350 (199) & $410(252)$ & $311(230)$ & $345(231)$ & $-0.8 \quad(-141$ to 125$)$ & NS \\
\hline Osmotic gap (mOsm/kg) & $139(61)$ & $137(51)$ & $115(55)$ & $126(36)$ & $-11.5(-40$ to 18$)$ & NS \\
\hline Faecal pH & $5.9(0.4)$ & $6.1(0.7)$ & $5.3(0.5) \dagger$ & $6.1(0.8)$ & $-0.6 \quad(-1.0$ to -0.2$)$ & NS \\
\hline Orofaecal transit time ( $\mathrm{min}$ ) & $336(243)$ & $324(284)$ & $489(259)^{\star}$ & $443(288)$ & $42 \quad(-116$ to 200$)$ & NS \\
\hline Breath $\mathrm{H}_{2}$ excretion $(\mathrm{ml})$ & $235(110)$ & $177(96)$ & $102(96) \ddagger$ & $191(103)$ & $-114(-171$ to -57$)$ & $<0.0001$ \\
\hline Faecal $\beta$-galactosidase activity (IU/g) & $10.1(5.6)$ & $10.6(6.6)$ & $20.2(15.3) \dagger$ & $6.7(3.7)^{\star}$ & $13.8(7.2$ to 20.4$)$ & $<0.0001$ \\
\hline
\end{tabular}

Results are expressed as means (SD).

${ }^{\star} \mathrm{p} v$ the same group during the first challenge on day $1<0.05 ; \mathrm{tp}<0.005 ; \mathrm{f}<<0.0001$.

feeding period (days 2 to 14). During this feeding period, they were randomly assigned to double blind administration twice daily of $17 \mathrm{~g}$ of either lactose $(n=24)$ or sucrose $(n=22)$ in $170 \mathrm{ml}$ water. To mask the difference in taste, $50 \mathrm{mg}$ aspartame was added to each preparation. Stool samples were obtained from all subjects on the day before each challenge (days 0 and 14 ) to measure faecal $\beta$-galactosidase activity and $\mathrm{pH}$. The lactose challenges lasted for 12 hours and were performed in a quiet room of the metabolic ward, where the volunteers sat reading in armchairs. After a 12 hour overnight fast, they ingested, at $0800 \mathrm{am}$, the test solution which consisted of $50 \mathrm{~g}$ lactose in $250 \mathrm{ml}$ water, to which $150 \mathrm{mg}$ aspartame and $1 \mathrm{~g}$ carmine red had been added. Clinical symptoms, breath $\mathrm{H}_{2}$ excretion, stool composition, and orofaecal transit time were determined during both challenges. Every hour, subjects reported any occurrence of abdominal pain, borborygmus, flatulence, and abdominal distension, and graded each symptom ${ }^{5}$ as absent (0), mild - that is, distinct but negligible (1), moderate - that is, annoying (2), or severe - that is, disabling (3). The total clinical score was calculated for each subject by summing the scores for each symptom (range 0-144). Breath samples were obtained by end expiratory sampling into plastic syringes using a modified Haldane-Priestley tube, before ingestion of the test solution and at 30 minute intervals thereafter. Each stool sample was collected in a preweighed container, immediately weighed, and frozen at $-20^{\circ} \mathrm{C}$. Stool colour was noted.

ASSAYS

The concentration of $\mathrm{H}_{2}$ was measured in breath samples using an electrochemical cell (Microlyzer DP, Quintron Instrument Co. Inc., Milwaukee, Wisconsin, USA). Stool samples were weighed, homogenised, and centrifuged. The supernatant of the faecal fluid was analysed for sodium and potassium using a flame photometer (Corning 480, Corning, Cergy Pontoise, France). Faecal $\mathrm{pH}$ was measured using a $\mathrm{pH}$ meter (PHM 82, Radiometer, Copenhagen, Denmark). Faecal $\beta$-galactosidase activity was measured by the release of $p$-nitrophenol from hydrolysis of $p$-nitrophenol- $\beta$-D-galactopyranoside. ${ }^{89}$
CALCULATIONS AND STATISTICS

The total volume of $\mathrm{H}_{2}$ excreted during the 12 hour sampling periods after ingestion of $50 \mathrm{~g}$ lactose was determined from the area under the $\mathrm{H}_{2}$ concentration curve over basal values. Tidal volumes were determined from the Radford nomogram $^{10}$ and results were expressed as $\mathrm{ml}$ $\mathrm{H}_{2}$ exhaled per 12 hours. The faecal osmotic gap was calculated according to the formula: faecal osmotic gap $=290-[(\mathrm{Na}+\mathrm{K}) \times 2] .^{11}$ Orofaecal transit time was defined as the interval between ingestion of the test solution and the appearance of carmine red in stools.

Data are expressed as mean (SD). Statistical analyses were performed with the PCSM statistical package (Deltasoft, Meylan, France) using Student's $t$ test and analysis of covariance. All tests were two tailed and the level of significance was set at $\mathrm{p}<0.05$.

\section{Results}

The lactose and sucrose groups did not differ with regard to age (34 versus 33 years) or sex ratio (11 versus 14 women). The results of the
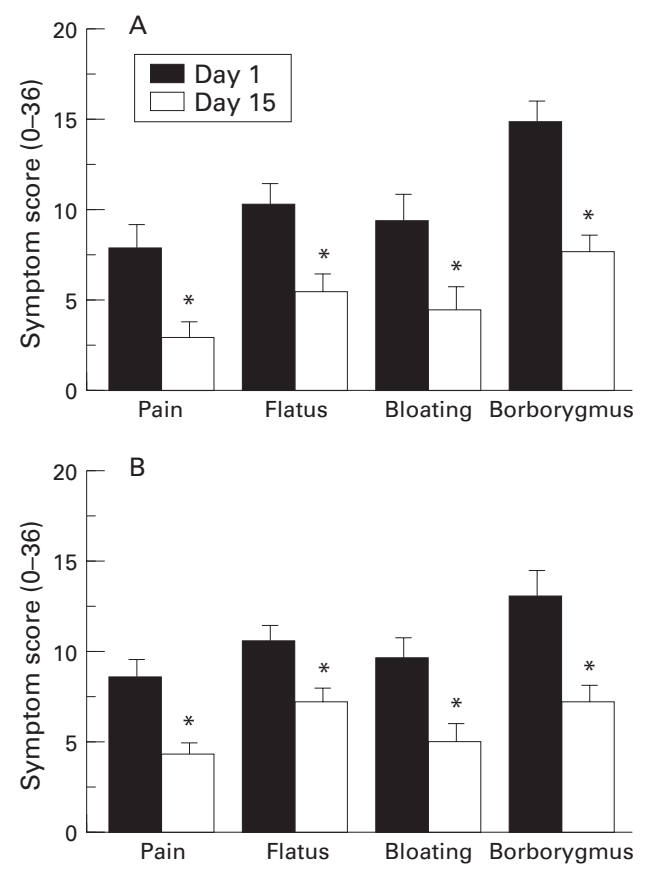

Figure 1: Symptoms reported by the 46 lactose maldigesters during two identical $50 \mathrm{~g}$ lactose challenges, separated by a 13 day period during which they consumed $34 \mathrm{~g}$ of either lactose or sucrose daily. Results are expressed as means (SD). 


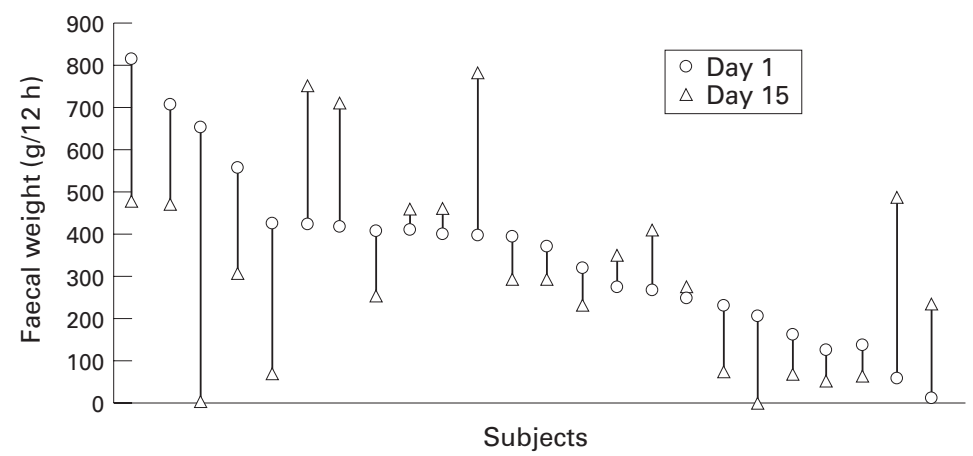

Figure 2: Individual results for faecal weight ( $g / 12 \mathrm{~h}$ ) of 24 lactose maldigesters during two identical 50 g lactose challenges, separated by a 13 day period during which they consumed $34 \mathrm{~g}$ of lactose daily. observed in the lactose group, and analysis of covariance confirmed that they were indeed specific to this group. We previously observed the same modifications during colonic bacterial adaptation to lactulose, a sugar closely related to lactose. ${ }^{4}$ The decrease in faecal $\mathrm{pH}$ due to the presence of short chain fatty acids produced during fermentation processes is a hallmark of the diarrhoea caused by carbohydrate malabsorption. ${ }^{15}$ The increase in faecal $\beta$-galactosidase activity was probably due to the induction of this enzyme by its substrate, and to shifts of the flora towards more acid resistant microorganisms, including lactic acid bacteria, which are good producers of $\beta$-galactosidase. ${ }^{42}{ }^{16}$ The decrease in breath $\mathrm{H}_{2}$ excretion after a second ingestion of the same lactose challenge was probably due to the acidification of the colonic content. ${ }^{1417}$

Except for stool weight, all symptomsabdominal pain, flatus, abdominal distension, borborygmus, and number of bowel movements-decreased between the first and second lactose challenges. If a control group had not been used, this would have led to the false conclusion that clinical improvement occurred as a result of the chronic lactose consumption. Hertzler and Savaiano recently reported the results of a blinded, controlled crossover study on the adaptation of lactose maldigesters to the ingestion of lactose or dextrose for 10 days. ${ }^{12}$ Their subjects were given a lactose challenge at the end of each period but there was no washout period. After regular lactose ingestion, metabolic adaptation of the flora occurred, and less flatus was noted than after dextrose, suggesting that the decline in symptom severity resulted from the metabolic adaptation. ${ }^{12}$ Our design and results differ from those of that study in that our lactose load was larger (50 versus about $24 \mathrm{~g}$ ), and the clinical symptoms were much more severe, especially diarrhoea, which was absent in Hertzler and Savaiano's study. In addition, our subjects were studied before and after adaptation, and a parallel and not a crossover design was used, with appropriate statistical analysis. As the same decrease in clinical symptoms was observed in the group given sucrose, which displayed no signs of metabolic bacterial adaptation, we conclude that there was no evident relation between the clinical improvement and metabolic bacterial adaptation.

Why were symptoms in the two groups less severe after the second lactose challenge than after the first? As lactose digestion is enhanced when gastric emptying and small intestinal transit time are slowed down, ${ }^{18}$ and as gastrointestinal motility can be influenced by stress, ${ }^{19}{ }^{20}$ a decrease in the degree of maldigestion of the lactose load might have occurred. However, this is unlikely, since it would have also resulted in a decrease in diarrhoea. It seems more likely that either the subjects became more adapted to the scoring system or that acclimatisation to the test procedures reduced the severity of the subjective symptoms by affecting visceral sensitivity and/or its pathways independently of any change in the extent of lactose digestion. 
The diarrhoea induced by the present lactose load remained unchanged, despite the metabolic adaptation of the flora, and the reduction in the other symptoms. This result is contrary to what we previously observed in healthy subjects ingesting lactulose regularly, in whom the metabolic adaptation mitigated the lactulose induced diarrhoea. ${ }^{5}$ There are three possible explanations for this discrepancy. Firstly, the sugar load during the test was larger in the earlier study (60 $\mathrm{g}$ of lactulose, which is totally indigestible in the small bowel, versus $50 \mathrm{~g}$ lactose in the present investigation), and diarrhoea was more abundant (820 versus $375 \mathrm{~g} / 12 \mathrm{~h}$ ); in the previous study, diarrhoea was mitigated but not suppressed, and even after adaptation to lactulose, faecal weight was still $490 \mathrm{~g} / 12 \mathrm{~h}$. One may postulate that the capacitance and/or motor response of the proximal colon to the arrival of chyme might only adapt above a certain threshold. Secondly, the dose of lactulose used for adaptation was $40 \mathrm{~g} /$ day, but in the present study, the amount of lactose actually reaching the colon was probably less than $20 \mathrm{~g} /$ day, as only part of the lactose is maldigested in lactose maldigesters. ${ }^{21}$ One may thus assume that the present lactose dose was high enough to induce metabolic adaptation of the flora, but too low to induce colonic adaptation of capacitance and/or motor activity. A third possible explanation for the absence of a decrease in stool weight after lactose ingestion is that different subjects were studied. The subjects in the present study were all of Asian origin, they had not participated in any previous study, and had been selected on the basis of the occurrence of diarrhoea during the lactose load. Diarrhoea is usually the last sign occurring in lactose intolerant subjects, and is often considered as a sign of severity. ${ }^{1}$ It is therefore possible that our selected subjects differed from normal subjects, and even from other lactose maldigesters, as regards the adaptation of their colon to osmotic loads.

In conclusion, several studies have shown that subjects with lactose maldigestion who complain of various symptoms of intolerance other than diarrhoea can at least tolerate small doses of lactose ingested with meals, and even doses as large as $70 \mathrm{~g} /$ day. $^{1{ }^{12}}$ However, our study strongly suggests that subjects with lactose induced diarrhoea should avoid ingestion of large doses of lactose in the fasting state, especially milk, because the improvement of diarrhoea is very unlikely. Consumption of lactose, either as fermented foods (especially yoghurt which contains lactase) or together with other foods ${ }^{121}$ should be recommended to this subset of subjects. The present study suggests the possibility that clinical improvement may sometimes simply be the result of familiarisation with the test procedures or placebo effect. Further studies on lactose tolerance need to be controlled, and should include accustomisation of the subjects to the test procedures and scoring systems.

1 Suarez FL, Savaiano DA, Levitt MD. Review article: the reatment of lactose intolerance. Aliment Pharmacol Ther 1995; 9: 589-97.

2 Scrimshaw NS, Murray EB. Adaptation of lactosemaldigesting individuals to milk and milk products. $A m \mathcal{F}$ Clin Nutr 1988; 48: 1118-9.

3 Johnson AO, Semenya JG, Buchowski MS, Enwonwu CO, Scrimshaw NS. Adaptation of lactose maldigesters to continued milk intakes. Am f Clin Nutr 1993; 58: 879-81.

4 Florent C, Flourié B, Leblond A, Rautureau M, Bernier JJ, Rambaud JC. Influence of chronic lactulose ingestion on Rambaud JC. Influence of chronic lactulose ingestion on
the colonic metabolism of lactulose in man (an in vivo study). F Clin Invest 1985; 75: 608-13.

5 Flourie B, Briet F, Florent C, Pellier P, Maurel M, Rambaud JC. Can diarrhea induced by lactulose be reduced by prolonged ingestion of lactulose? Am f Clin Nutr 1993; 58: 369-75

6 Vesa TH, Korpela RA, Sahi T. Tolerance to small amounts of lactose in lactose maldigesters. Am F Clin Nutr 1996; 64: $197-201$.

7 Suarez F, Levitt MD. Abdominal symptoms and lactose: the discrepancy between patients' claims and the results of blinded trials. Am f Clin Nutr 1996; 64: 251-2.

8 Yuen CT, Price RG, Chatagoon L, Richardson AC, Praili PFG. Colorimetric assays for N-acetyl- $\beta$-D-glucosaminidase and $\beta$-D-galactosidase in human urine using newly developed $\omega$-nitrostyryl substrates. Clin Chim Acta 1982; 124: 195-204.

9 Marteau P, Pochart P, Flourié B, Pellier P, Santos L, Desjeux JF, et al. Effect of chronic ingestion of a fermented Desjeux JF, et al. Effect of chronic ingestion of a fermented
dairy product containing Lactobacillus acidophilus and daify product containing Lactobacillus acidophilus and colonic flora in man. Am f Clin Nutr 1990; 52: 685-8.

10 Radford EP, Ferris BG, Kriete BC. Clinical use of a nomogram to estimate proper ventilation during artificial respiration. $N$ Engl f Med 1954; 251: 877-84

11 Fine KD, Krejs GJ, Fordtran JS. Diarrhea. In: Sleisenger $\mathrm{MH}$, Fordtran JS, eds. Gastrointestinal diseases. 5th edn. Philadelphia: Saunders, 1993: 1043-72.

2 Hertzler SR, Savaiano DA. Colonic adaptation to daily lactose feeding in lactose maldigesters reduces lactose intolerance. Am f Clin Nutr 1996; 64: 232-6.

13 Pochart P, Bisetti N, Bourlioux P, Desjeux JF. Effect of daily consumption of fresh or pasteurized yogurt on intestinal lactose utilisation in lactose malabsorbers. Microecol Ther 1989; 18: 105-10.

14 Perman JA, Modler S, Olson AC. Role of the $\mathrm{pH}$ in production of hydrogen from carbohydrate by colonic bacterial tion of hydrogen from carbohydrate

15 Eherer AJ, Fordtran JS. Fecal osmotic gap and $\mathrm{pH}$ in experimental diarrhea of various causes. Gastroenterology 1992; 103: 545-51.

16 Hill MJ. Bacterial adaptation to lactase deficiency. In: Delmont J, ed. Milk tolerance and rejection. Basel: Karger, 1983: 22-6

17 Vogelsang H, Ferenci P, Frotz S, Meryn S, Gangl A. Acidic colonic microclimate-possible reason for false negative hydrogen breath tests. Gut 1988; 29: 21-6.

18 Martini MC, Savaiano DA. Reduced intolerance symptoms from lactose consumed during a meal. Am f Clin Nutr 1988; 47: 57-60.

19 Beaugerie L, Burger AJ, Cadranel JF, Lamy P, Gendre JP, Le Quintrec Y. Modulation of orocaecal transit time by hypnosis. Gut 1991; 32: 393-4.

20 Cann PA, Read NW, Cammack J, Childs H, Holden S, Kashman R, et al. Psychological stress and the passage of a standard meal through the stomach and small intestine in man. Gut 1983; 24: 236-40.

21 Marteau P, Flourié B, Pochart P, Chastang C, Desjeux JF, Rambaud JC. Role of the microbial lactase (EC 3.2.123) activity from yogurt in the intestinal absorption of lactose: an in vivo study in lactase deficient humans. Br 7 Nutr 1990; 64: 71-9. 